At-Tijaroh: Jurnal Ilmu Manajemen dan Bisnis Islam

Volume 7 (2), 2021: 141 - 157

P-ISSN: 2356-492X; E-ISSN: 2549-9270

\title{
CAN ISLAMIC FINANCE DRIVES ECONOMIC GROWTH? : EMPIRICAL EVIDENCE FROM INDONESIA
}

\author{
Budi Trianto ${ }^{1}$, Masrizal ${ }^{2}$, Tasiu Tijjani Sabiu ${ }^{3}$ \\ budi asamandiri@yahoo.com ${ }^{1}$, masrizalriza195@gmail.com ${ }^{2}$, \\ ttsabiu@yumsuk.edu.ng ${ }^{3}$
}

\begin{abstract}
The purpose of this paper is to analyze the contribution of Islamic finance to Indonesian economic growth in view Global Islamic Finance Report which places Indonesia as number 1 globally in terms of Islamic Finance Country Index for the year 2019. Using quarterly dataset (2013:1-2018:4), this paper study employs ARDL framework and bounds testing approach to co-integration to investigate the influence of Islamic finance on Indonesian economic growth. The results show that in the long run Islamic finance is positive and significantly correlated with economic growth of Indonesia. The result obtained from Error correction model reveal a positive and significant long run causal effect of Islamic finance on Indonesian's economic growth. However, Indonesian Islamic capital market is found not to have a significant long run causal effect on the country's economic growth.
\end{abstract}

Keywords: Islamic finance, Economic Growth; ARDL; Indonesia

Received: xxxx 2021; Revised: xxxx, 2021; Accepted: xxxxxxx, 2021

1,2,STEI Iqra Annisa Pekanbaru, Indonesia

${ }^{3}$ Yusuf Maitama Sule University, Kano, Nigeria

E-mail: ${ }_{1}$ budi asamandiri@yahoo.com, masrizalrizal95@gmail.com, ttsabiu@yumsuk.edu.ng

DOI: https://doi.org/10.24952/tijaroh.v6i2.2453 


\section{Introduction}

An economic system requires harmony and balance between sectors, such as the real and financial sectors. The real sector needs funds from the financial sector as a source of financing in the framework of the production process. Vice versa, the financial sector needs the real sector as a medium to invest in available funds (Hadi, 2015). Strong evidence of the growing popularity of Islamic financial products and instruments after the crisis global financial market. The increasing demand for Islamic financial products and investments including Islamic bonds, Islamic stock market, exchange-traded Islamic mutual funds, Islamic insurance (takaful) is evidence that supports the growing popularity of Islamic financial markets. In the last two decades, the Islamic finance industry globally has shown quite rapid development. In recent years there has been significant growth in the Islamic financial industry, especially in the Middle East and Southeast Asian countries that grew after the 2008-2009 global financial crisis (GFC). The total amount of sharia financial assets managed is estimated at US \$ 1.6 trillion at the end of 2012 and US \$ 1.8 trillion at the end of 2013, touching US \$ 2.1 trillion at the end of 2014 and estimated at US $\$ 6.5$ trillion in the year 2020. (Hammoudeh, Mensi, Reboredo, \& Nguyen, 2014).

Likewise, Indonesia continues to strive to develop Islamic finance. The development of the Islamic financial industry shows a significant development in the global arena. This can be seen from the publication of the Global Islamic Finance Report which places Indonesia at number 1 of the Islamic Finance Country Index for 2019 (Global Islamic Finance Report, 2019). In recent years, the relationship between financial development and economic growth has been the main subject in the field of economic development (Grassa \& Gazdar, 2014). Economists have been interested in the role of financial institution expansion in allocating resources to economic growth. Some researchers agree that the importance of the role of the financial sector in increasing real growth, both at national and international levels (Zarrouk, El Ghak, \& Abu Al Haija, 2017). The theoretical foundation of this relationship can be traced from the work of Joseph Schumpeter in the early twentieth century, King and Levine (1993) as well as Levine, (1997) who show the important role played by the financial sector via directing financial resources to the deficit sectors and thereby contributing to the recall of productivity and economic growth. Islamic banking plays at least four important roles: encouraging loans, stimulating savings, increasing financial stability, and contributing to financing based on Islamic principles. Islamic finance is 
Budi Trianto, Masrizal, Tasiu Tijjani Sabiu. Can Islamic Finance Drives Economic Growth?: Empirical Evidence from Indonesia

considered a stable financing system and can encourage growth and create long-term employment (Boukhatem \& Ben Moussa, 2018).

The interest in the issue of Islamic banking and finance is not only due to rapid growth but is based on recurring financial crises over the last decade with the global crisis in 20072009 so severe. total sharia-managed financial assets are estimated at US \$ 1.6 trillion at the end of 2012 and US \$ 1.8 trillion at the end of 2013, reaching US \$ 2.1 trillion at the end of 2014 and estimated at US $\$ 6.5$ trillion by 2020 At present, the Islamic financial sector is no longer a business entity that is only operated to fulfill religious obligations, but it is a necessity. Motivated by the resilience of Islamic finance during the crisis and rapid development in recent years, the researchers focused their studies on comparative analysis of Islamic and conventional banks, risk/stability, efficiency, and financing. The increasing growth of Islamic financial assets globally raises the question of whether Islamic finance has a role in global financial intermediation. Naqvi, Rizvi, Uqaili and Chaudhry (2018) examines whether Islamic banks can contribute to global financial re-intermediation? Providing answers that using data from 486 conventional banks and 154 Islamic banks from 21 countries shows that Islamic banks have a high intermediation ratio compared to conventional banks for the entire sample period and among the CAMELS variables, asset growth and bank loans, loan to deposit and loan ratios as the ratio of total productive assets.

Imam and Kpodar (2016) in their research addressed whether the development of Islamic banking is good for economic growth. Using from 52 countries with data covering the period 1990-2010, the results illustrate that although its size is relatively small compared to the economy and the overall size of the financial system; Islamic banking is positively related to economic growth. Islamic banking supports economic growth through two main channels namely capital accumulation and increased financial inclusion with greater access to deposits. Islamic banking, which is one of the fastest-growing global financial segments, has unique features. Specifically based on the distribution of risks that make activities more closely related to the real economy. Thus, there is great uncertainty about the impact of the growth of Islamic banking. For this reason, further research is recommended because Islamic banks have much larger diffusion by looking at developments at the local level.

Indonesia has the largest Muslim population in the world, and Islamic banking has gained a great appeal with Indonesian banks highlighting 65\% growth in Islamic banking assets over the past five years (Rizvi, Narayan, Sakti, \& Syarifuddin, 2019). Indonesia has a large market share and the potential to develop Islamic finance. Based on Law 2008 which 
is legal protection for sharia banking, all sharia business units (UUS) must stand alone 15 years after the 2008 law on sharia banking was issued. In other words, in 2023 all Sharia Business Unit Compulsory Islamic banks (BUS). Islamic banking as part of the national banking system has an important role in the economy. The existence of Islamic banking in the national banking system in Indonesia is expected to encourage the development of the national economy. This is also in line with the Indonesian Islamic banking roadmap (20152019), namely realizing sharia banking that contributes significantly to sustainable economic growth, equitable development, and financial system stability and high competitiveness. Thus it is necessary to research the development of Islamic finance on national economic growth.

Empirically, there exist considerable literatures that link conventional finance and economic growth. However, Islamic finance and economic growth literatures received meager attention in relation to its conventional counterpart. Thus, studies that highlights the role of Islamic banking towards economic growth are limited, especially in the context of Indonesia. This paper therefore uses empirical evidence to demonstrate the role of Islamic banks' financing towards economic performance of a Indonesia

\section{Literature review}

Even though Islamic and conventional banks are the same as intermediary institutions, they differ in operational terms. Islamic banking is based on Islamic principles outlined in the Qur'an and the hadith of Islamic jurisprudence. Another important feature of Islamic banks is that they are not permitted to engage in speculative transactions such as derivatives and gambling that are not in accordance with Islamic principles. Investments in conventional banks lead to risk transfers while Islamic banks share risks and can only provide credit to finance productive investments. Every transaction made by Islamic banks must be supported by real assets while conventional banks can provide credit without such obstacles. In addition, Islamic banks cannot generate profits based on pure financing so they must engage in investment or sales transactions and share both in risk and return (Caporale, Çatık, Helmi, Menla Ali \& Tajik, 2019).

Financial markets are a key factor in economic growth because they divert financial funds from unproductive to productive (Durusu-Ciftci, Ispir, \& Yetkiner, 2017). The view of Schumpeter (1912) is considered as the main work in analyzing the financial sector and economic growth. In his study Schumpeter shows that the banking system is an important factor for economic growth because of its role in the allocation of savings, investment 
Budi Trianto, Masrizal, Tasiu Tijjani Sabiu. Can Islamic Finance Drives Economic Growth?: Empirical Evidence from Indonesia

encouragement and funding for productive investment. Economists and researchers have become increasingly interested in looking at the relationship between financial development and economic growth, because previous empirical studies have shown conflicting results. Some of them identified positive correlative results and some identified doubtful results.

Important studies from this study also try to prove the relationship between financial development and economic growth. Some find a one-way relationship (unidirectional causality), some researchers also prove the existence of a two-way relationship (bi-directional causality). But there are also some studies that show that there is no causal relationship between financial development and economic growth. It is well recognized, that financial markets are very important for economic growth because they encourage the mobilization of unemployed deposits and turn them into useful and productive capital. However, when the economy grows, it will produce a surplus which triggers the growth of the financial sector. Thus the direction of causality between financial development and economic growth is ambiguous and open for further investigation.

Beck and Levine (2004) examined the relationship of the stock market, banks and growth using panel analysis. Using quarterly data from 1976-1998 from 40 countries with 146 observations. By using three alternative panel specifications, the Results show that it strongly rejects the idea that financial development as a whole is not important or dangerous for growth. In other words, financial development plays a positive role in the process of economic growth.

Carp (2012) examined capital market floating on Romanian economic growth using data from 1995-2010 with VAR analysis and Granger Causality. The findings show that higher economic growth rates must be stimulated by real investment which indirectly results in positive externalities on the stock market indicators. Grenger Causality's analysis shows that market capitalization and the value of traded shares have no impact on the rate of economic growth, indicating the development of the stock market at a low level thereby reducing its role in the Romanian economy.

Adu, Marbuah and Mensah (2013) examined financial development and economic growth in Ghana. Using an annual sample from 1961-2010 with ARDL analysis. The results show that for the condition of using the ratio of private sector credit to GDP or private sector credit as a ratio to total credit found a significant positive effect of financial development on economic growth. Ben Jedidia, Boujelbène and Helali, (2014) examined the financial development and economic growth in Tunisia during the 1973-2008 period with 
the Autoregressive Distributed Lag (ARDL) approach. Empirical results show that domestic credit to the private sector has a positive effect on economic growth. In other words, financial development is a driver of long-term economic growth, but not short-term.

Durusu-Ciftci et al., (2017) examined the effect of financial development on economic growth using annual data from 1989-2011 in 40 countries through the Augmented Mean Group (AMG) and Common-Correlated Effects (CCE) approaches. Panel analysis revealed that bank credit and stock market development had a positive effect on economic growth and substantially greater bank credit contributions. Pan and Mishra (2018) tested the stock market mining and economic growth in China. They collected monthly data on market capitalization of A shares on the Shanghai stock exchange, market capitalization of A shares on the Shenzhen stock exchange, market capitalization of Shares B on the Shanghai stock exchange and market capitalization of B shares on the Shenzhen stock exchange. The period of stock market capitalization, IP index and number of monthly transactions is from January 1999 to November 2015. The period for equally weighted sectoral indices and stock market indices is from July 2005 to November 2015 using the ARDL approach and Toda Yamamoto's (1995) Causality Test. The results show the Shanghai A stock market which shows a long-term stochastic trend with the real economy and a small but negative influence on the real economy. Furthermore, Toda Yamamoto's approach is used to test financial growth empirically. The demand-driven hypothesis is only supported on the Shenzhen B stock market. The Shenzhen B stock market and the real economy support the view that any economic growth will affect the financial markets, which represent a causal relationship between growth in real economic output and stock market growth.

An incompatible relationship can be found from Gregorio and Guidotti's (1992) research finding a negative and significant impact on financial development on growth for Latin American countries. Favara (2013) empirically examined the relationship between financial development and growth based on various econometric methods. With the estimation of GMM dynamic panel data, the development of finance and growth is unrelated and based on pooled Mean Group is also ambiguous and not strong. From the perspective of Islamic banking, they contribute to economic growth. Combining ethical and moral values in financing increases the motivation of Muslims to mobilize funds to the real sector for venture capital. Moreover, the risk sharing aspect encourages Islamic banks to be more careful in their loan financing decisions and consequently allocate liquidity more optimally than conventional banks. Thus it is expected that the impact of Islamic finance on economic 
Budi Trianto, Masrizal, Tasiu Tijjani Sabiu. Can Islamic Finance Drives Economic Growth?: Empirical Evidence from Indonesia

development will be more important (Zarrouk et. al., 2017). This is supported by Grassa and Gazdar (2014) who examined the effect of financial developments on economic growth in GCC countries. Specifically trying to compare the effect of developing Islamic finance and developing conventional finance on economic growth for the five GCC countries (Bahrain, Kuwait, Qatar, Saudi Arabia and the UAE) from 1996-2011 using OLS and GLS estimates. The results showed that the development of conventional finance significantly affected the economic growth of GCC countries. While the development of the Islamic banking sector is a relevant determinant for economic growth in the GCC countries. More interestingly Sukuk market representing the capital market in the GCC countries does not contribute to economic growth. In this way, Islamic banks have emerged as a determinant of relevant economic growth in the GCC countries. In other words, Islamic finance does better than conventional finance for better economic development.

Mohd. Yusof and Bahlous (2013) examined the short-term and long-term dynamics between Islamic banking and economic growth during the 2000-2009 period in the GCC countries and East Asia using panel cointegration of pedronies, VDCs and impulse response functions. The results show that in line with Islamic financial principles which state Islamic banking provides efficient channels for productive resources to be transmitted to economic growth. The results also support the view that Islamic intermediation not only leads to economic benefits but also enhances managerial entrepreneurial skills through lender involvement in decision making and partnerships such as relationships between fund providers and entrepreneurs and also reduces agency costs that have a positive impact on the economy and development society. Lebdaoui and Wild (2016) examined the relationship of Islamic banking and economic growth in Southeast Asian countries using the Lag Distribution Autoregrereive Panel (ARDL): Pool mean Group, mean group (MG) and dynamic fixed effect (DFE) from 2000Q1 to 2012Q4. The results show that there is a longterm relationship between economic growth and the existence of Islamic banking. In addition, the share of the Muslim population in certain countries plays a positive and statistically significant role in triggering the contribution of the share of Islamic banking in the financial sector to economic growth. Abduh and Chowdhury (2012)examined the relationship of Islamic banking to economic growth in Bangladesh from 2004: Q1 to 2011Q2. Using the cointegration test method and the Gate of Causality shows the results that Islamic banking has a significant positive impact on economic growth both in the short and long term. A similar sentiment was also stated by Abduh and Omar, (2012) examining 
the short and long-term relationship between the development of Islamic banks and Indonesia's economic growth from 2003: 1 to 2012: 2. Using the Autoregressive Distributed Lag test (ARDL) shows the results that a significant relationship in the short and long term period between the development of Islamic finance and economic growth and has a bidirectional relationship.

Furqani and Mulyany (2009), Abd. Majid and Kassim (2015) as well as Kassim (2016) examined the influence of Islamic banking and economic growth in Malaysia. The results show that developing the Islamic banking and financial industry is one of the relevant policy options to drive economic growth in Malaysia. This shows that Islamic banks in Malaysia effectively carry out the role of financial intermediation to collect and channel funds for productive investment activities. But it is not in line with research by Hachicha and Ben Amar (2015)which shows that in the long run, Malaysian GDP is not so sensitive to Islamic financing.

Furthermore, Goaied and Sassi (2010) empirically used unbalanced panel data from 1962 to 2006 for 16 countries in the Middle East and North Africa (MENA) regions using the GMM method. The results show that there is no significant relationship between the development of Islamic banking and economic growth. Even Islamic banks in particular show a weak relationship with economic growth.

From the empirical studies above, statistical bias can occur due to variable problems. For a small open economy like Indonesia, the external sector plays an important role. In addition, macroeconomic stability is likely to influence the development of the Islamic financial sector and real economic activity. Thus this study aims to look at the effect of Islamic financial development on Indonesia's real sector by including the external sector as other determining variables such as inflation and gross fixed capital formation.

\section{Methodology}

\subsection{Variables and Data Sources}

This study examines the effect of Islamic finance on economic growth in Indonesia using quarterly data from Q1: 2003 to Q4: 2018. To represent the real economic sector, GDP is used as the dependent variable. As for the Independent variable, two indicators of Islamic financial development are used and several macroeconomic indicators are considered. First, the total financing used by Islamic banks as the ability of Islamic banks to finance the real economic sector. Second, the Islamic capital market is proxied by the market capitalization 
Budi Trianto, Masrizal, Tasiu Tijjani Sabiu. Can Islamic Finance Drives Economic Growth?: Empirical Evidence from Indonesia

value of the Jakarta Islamic Index source from the companies getting additional capital which used to developing the company and increasing production.

Other independent variables are gross fixed capital formation (GFC), trade, and inflation. GFC is a proxy of investment. Kassim (2016) states that GFC is one of the main channels through which financial intermediaries can influence growth. in order to avoid the bias of other variable models included in this study. Yusof and Bahlous (2013) submit that Trade takes into account the price of oil and all other exports that affect the GDP of the country under study. While inflation is an indicator of price stability in the economy, its appropriate time has an impact on consumption, savings and investment decisions. The selection of variables in this study is in line with Islamic finance finance-growth nexus literature (see Abduh \& Omar, 2012; Mohd. Yusof \& Bahlous, 2013; Abd. Majid \& Kassim, 2015; Hachicha \& Ben Amar, 2015; Kassim, 2016; Lebdaoui \& Wild, 2016; Boukhatem \& Ben Moussa, 2018; Pan \& Mishra, 2018). Data for the development of Islamic finance was

obtained from Islamic banking statistical reports published by the Financial Services Authority $(\mathrm{OJK})$, and other variable data was obtained from the International Monetary Fund International Financial Statistics database.

\subsection{Estimating Model}

Applying the right methodology for time series data is the most important part of time series analysis so as not to provide biased and unreliable models or estimates. In this study, the short-term and long-term dynamic relationship between Islamic finance and growth uses the ARDL approach as presented by Pesaran, Shin, \& Smith, (2001) which can be applied regardless of whether all variables are I (0), I (1), or are usually coordinated. Here we estimate the ARDL model :

$$
\ln G D P t=a_{0}=a_{1} \operatorname{lnFN} N_{t}+a_{2} J I I_{t}+a_{3} \operatorname{lnGFC_{t}}+a_{4} \operatorname{lnTRADE} E_{t}+a_{5} I N F_{t}+e_{t}
$$

Where GDP is the real output at time t, FN is total Islamic banking financing, JII is the capitalization of the Jakarta Islamic index, TRADE is the volume of trade as a percentage of GDP and INF is inflation. 


$$
\begin{aligned}
\Delta \ln G D P_{t}=\beta_{0} & +\sum_{i=1}^{p} \beta_{1} \Delta \ln G D P_{t-i}+\sum_{i=0}^{p} \beta_{2} \Delta \ln F N_{t-i} \\
& +\sum_{i=0}^{p} \beta_{3} \Delta \ln J I I_{t-i}+\sum_{i=0}^{p} \beta_{4} \Delta \ln G F C_{t-i} \\
& +\sum_{i=0}^{p} \beta_{5} \Delta \ln T R A D E_{t-i}+\sum_{i=0}^{p} \beta_{6} \Delta \ln I N F_{t-i}+\emptyset E C T_{t-1}+\mu t
\end{aligned}
$$

Where ECM is an error correction term. However, cointegration only implies a causal relationship but does not indicate its direction.

\section{Results and Discussion}

\subsection{Unit Root Test Results}

Although the ARDL approach can be applied to integrated variables of order zero or one representing $\mathrm{I}(0)$ or $\mathrm{I}(1)$ respectively. Stationary tests are needed to verify that none of variables are integrated of order two or I (2). Unit root test employing Augmented Dicker Fuller (ADF) and Philips Peron (PP) tests were executed based on constant and trend. Considering both unit root test results of $\mathrm{ADF}$ and $\mathrm{PP}$, table 1 below shows a mixture of variables stationary at level and first difference. In addition, the variables $\ln G D P, \operatorname{lnFN}$, JII, lnGFC, InTRADE, INF are not integrated of order two or I (2). This permits applying of ARDL approach to co-integration.

Table 1. Unit Root Test Results

\begin{tabular}{lllll}
\hline \multicolumn{1}{c}{ Variables } & \multicolumn{2}{c}{ ADF } & \multicolumn{2}{c}{ PP } \\
\hline LNGDP & -1.471362 & $-4.631879^{* * *}$ & $-4.496515^{* * *}$ & $8.085114^{* * *}$ \\
LNFN & -0.408730 & $-4.484303^{* * *}$ & $-7.514231^{* * *}$ & $7.705436^{* * *}$ \\
JII & -1.568456 & $-6.475245^{* * *}$ & -1.588811 & $6.597507^{* * *}$ \\
LNGFC & 1.591525 & $-1.643169^{*}$ & $-6.909076^{* * *}$ & $7.623219^{* * *}$ \\
LNTRADING & -2.006682 & $-7.326853^{* * *}$ & -1.995829 & $7.328439^{* * *}$ \\
INF & -0.23978 & $-7.965845^{* * *}$ & -0.234344 & $8.029881^{* * *}$ \\
\hline
\end{tabular}

Note that: * Significant at 10\%; ** Significant at 5\%; *** Significant at 1\%

Source : Authors Calculation, 2021.

\subsection{Result of the Cointegration Test: Bounds F-test}


Budi Trianto, Masrizal, Tasiu Tijjani Sabiu. Can Islamic Finance Drives Economic Growth?: Empirical Evidence from Indonesia

The Co-integration test result in table 2 below shows that the F-statistic value is greater than the upper critical value at $1 \%$. and $5 \%$ based on unrestricted intercept and no trend. The null hypothesis of no co integration is rejected. This indicate an evidence of the longrun co-movement between the variables exhibiting the propensity to proceed together in the long run.

Table 2. Bounds F-test Result

\begin{tabular}{cccccc}
\hline & & & \multicolumn{2}{c}{ Bound Critical Values } \\
\cline { 4 - 5 } Equations & Lag & F-Statistics & Sig.level $(\%)$ & Lower Bounds & Upper Bounds \\
\hline 2 & 5 & 17.95951 & $1 \%$ & 3.41 & 4.68 \\
& & & $5 \%$ & 2.62 & 3.79 \\
& & & $10 \%$ & 2.26 & 3.35 \\
\hline
\end{tabular}

Source : Authors Calculation, 2021

\subsection{Estimates of Long-run Relationship}

Following evidence of long run co-integration or association among gross domestic product, Islamic bank financing, Islamic capital market, gross fixed capital formation and trade, the next stage is to estimate long run coefficient among the variables. The ARDL long run coefficients showcase the nature of the relationship among GDP and the regressors employed in the model. Result estimates of the long run relationship in Table 4 show a positive relationship among gross domestic product and Islamic bank financing. The result indicates that any $1 \%$ increase in Islamic bank financing will result to $0.43 \%$ increase in economic growth. Thus, financial intermediation is guaranteed to make a positive contribution to economic growth in Indonesia and this is in line with Naqvi, Rizvi, Uqaili and Chaudhry (2018). The positive contribution of Islamic finance to economic growth is also consistent with Abd. Majid and Kassim (2015), Abduh and Chowdhury (2012), Abduh and Omar (2012), Furqani and Mulyany (2009), Kassim (2016), Lebdaoui and Wild (2016), Mohd. Yusof and Bahlous (2013), Sabiu and Abduh (2020) as well as Zarrouk et al., (2017), but not supported with the findings Hachicha and Ben Amar, (2015) as well as Goaied and Sassi (2010). While JII as an indicator of the Islamic capital market does not drive significant on economic growth, it is in line with findings Carp, (2012) confirming that stock capitalization has no impact on the Rumanian economy. Other findings in this study indicate that GFC, TRADE, and Inflation are contributing to Indonesia's economic growth. A strong contribution was generated by GFC. This is in line with the study of Himawan (2015) who examined the effect of GFC, Trade and FDI on Indonesia's economic growth from 1981 to 
2013. The finding of the study confirms that GFC greatly contributed to Indonesia's economic growth.

Table 4. ARDL Estimate of Long-run Relationship

Dependent Variable: GDP ARDL $(1,3,0,3,0,0)$

\begin{tabular}{lrrr}
\hline Regressors & Coefficient & t-statistic & Prob. \\
\hline LNFN & $0.004256^{* * *}$ & 3.062026 & 0.0036 \\
JII & 0.000009 & 0.266541 & 0.7910 \\
LNGFC & $0.450186^{* * *}$ & 18.892261 & 0.0000 \\
LNTRADE & $0.143777^{* * *}$ & 6.924564 & 0.0000 \\
INF & $0.008058^{* * *}$ & 16.131441 & 0.0000 \\
C & 9.768266 & 36.400986 & 0.0000
\end{tabular}

Note: Significant at: $* 10, * * 5$ and $* * * 1$ percent levels

\subsection{ECM Long run Causality}

Having found longrun cointegration among GDP, Islamic bank financing, Islamic capital market, trade and inflation as well as the long run coefficients, the next step entails determining if the model converge to long run equilibrium following shocks in the short run. The error correction term in table 5 is negative and statistically significant which shows a proof of feedback effect or convergence to long run equilibrium and also an indication a long run causality in at least one direction. The overall ECM coefficient suggests that previous deviation from long run equilibrium is corrected at the speed of $111.5 \%$. The result in table 5 reveals that Islamic bank financing (LNFN) has a significant positive long run effect on economic growth (GDP). Therefore, a 1\% increase in Islamic bank financing will lead to increase in Indonesian economic growth by $0.0065 \%$. The findings of positive long run causal effect is consistent with the work of Abduh and Omar (2012) in Indonesia, as well as Farahani and Dastan (2013) for nine Islamic countries including Indonesia. 
Budi Trianto, Masrizal, Tasiu Tijjani Sabiu. Can Islamic Finance Drives Economic Growth?: Empirical Evidence from Indonesia

Table 5.Error Correction Model and Diagnostic Test

\begin{tabular}{lr}
\hline & $\Delta$ LNRGDP \\
\hline ECT $_{\mathrm{t}-1}$ & $-1.115(-8.897)^{* * *}$ \\
Coefficient of $\Delta \mathrm{LNFN}$ & $0.0065(3.193)$ \\
Coefficient of $\Delta \mathrm{JII}$ & $0.000(0.265)$ \\
Coefficient of $\Delta \mathrm{LNGFCF}$ & $0.383(5.088)^{* * *}$ \\
Coefficient of $\Delta \mathrm{TRADE}$ & $0.160(6.191)^{* * *}$ \\
Coefficient of $\Delta \mathrm{INF}$ & $0.009(8.194)$ \\
Diagnostic Tests & \\
Glejser test & 0.1703 \\
JB normal & 0.208647 \\
F- Statistics & 7213.472 \\
P-value & 0.000000 \\
Adjusted $\mathrm{R}^{2}$ & 0.999307 \\
\end{tabular}

Note: Significant at: $* 10, * * 5$ and $* * * 1$ percent levels

The result further shows that that gross fixed capital formation (GFCF) has a positive long run causal effect on economic growth at 1\% level of significance. Precisely, a 1\% increase in gross fixed capital formation (GFCF) will lead to 38.3\% increase in Indonesian economic growth. The long run causality in respect of Islamic capital market though it's positive which conform to theoretical criterion but has insignificant effect on Indonesian economic growth. The result in table 6 further reveals that trade has a significant positive effect on economic growth (GDP) at 1\% level of significance. Specifically, a 1\% increase in trade will lead to $16 \%$ increase in Indonesian economic growth. Finally, The long run causality with regard to inflation (INF) also exert a significant positive effect on Indonesian economic growth. Thus, a $1 \%$ rise in consumer price index will increase economic growth (GDP) by $0.9 \%$.

\subsection{Diagnostics Tests}

Diagnostic test on the ECM were conducted to verify the competency of the model. The result in Table 5 show that Glejser test indicate no econometric problem of heteroskedasticity. Also, Jarque Bera normality test reveals that the errors in the model are normally distributed.

Figure 1. CUSUM of Squares Test for Stability 


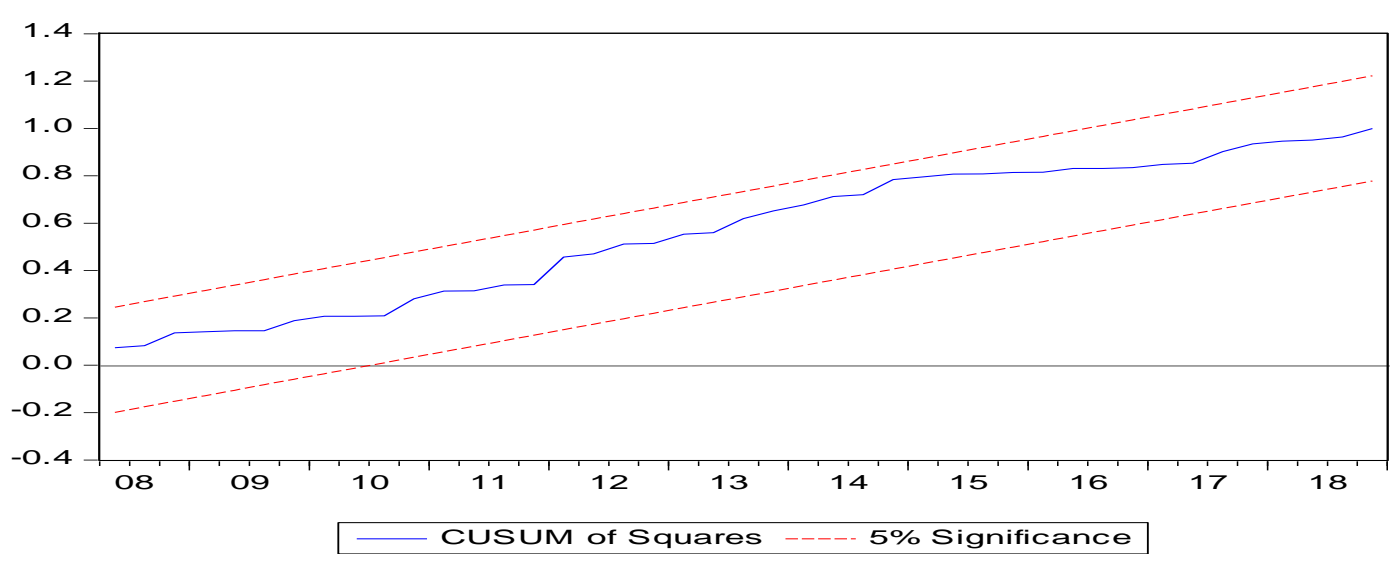

Finally, regression estimates stability is tested using cumulative sum of squares (CUSUMSQ) and its test value in figure 1 appears stable as the regressed line falls within the critical bounds at 5\% significance level. Thus, the variance estimates of the error correction model is satisfactory as it remains constant and stable over time. Therefore, ARDL model estimated in the study is robust in gauging the link between Islamic finance and economic growth in Indonesia.

\section{Conclusions}

The increasing proportion of assets that highlights $65 \%$ growth over the past five years makes a great attraction expected to play a role in improving the Indonesian economy. This study looks at the role of Islamic finance in the economy using the ARDL technique and the boundary testing approach for cointegration. The results of this study indicate that Islamic bank financing provides a significant contribution to economic growth. The existence of Islamic banking in the national banking system in Indonesia can drive the development of the national economy. The contribution of Islamic finance in the economy is made possible by the Islamic principles adopted in the operation of Islamic banks namely the prohibition of interest. Interest is one of usury practices. Interest is positively correlated with supply of investment funds, but it negatively correlated with demand for funds (credit or investment). If interest rises, it will increase the supply of funds (savings) and decrease the demand of funds.

The decrease in demand of funds means a decline in investment, so it will be a negative impact on the economy namely economic growth decrease. On the other hand, profit sharing has a positive impact on economic growth. The principle of profit-sharing applied by Islamic banking is an indicator for increasing the economic output. Profit-sharing will increase 
Budi Trianto, Masrizal, Tasiu Tijjani Sabiu. Can Islamic Finance Drives Economic Growth?: Empirical Evidence from Indonesia

investment and also increase production activities. In view the contribution made by Islamic finance to the Indonesian economy, sustainable efforts need to further expand this industry. Thus strengthening the 2019 Global Islamic Financial Report (GIFR) places Indonesia as the number one ranking in terms of leadership and potential in Islamic banking and finance, and it can realize the vision of making Indonesia the leading center of Islamic economics in the World.

\section{References}

Abd. Majid, M. S., \& H. Kassim, S. (2015). Assessing the contribution of Islamic finance to economic growth: Empirical evidence from Malaysia. Journal of Islamic Accounting and Business Research, 6(2), 292-310. https://doi.org/10.1108/JIABR-07-2012-0050

Abduh, M., \& Azmi Omar, M. (2012). Islamic banking and economic growth: the Indonesian experience. International Journal of Islamic and Middle Eastern Finance and Management, 5(1), 35-47. https://doi.org/10.1108/17538391211216811

Abduh, M., \& Chowdhury, N. (2012). Does Islamic banking matter for economic growth in Bangladesh? Journal of Islamic Economics, Banking and Finance, 8(3), 104-113.

Adu, G., Marbuah, G., \& Mensah, J. T. (2013). Financial development and economic growth in Ghana: Does the measure of financial development matter? Review of Development Finance, 3(4), 192-203. https://doi.org/10.1016/j.rdf.2013.11.001

Beck, T., \& Levine, R. (2004). Stock markets, banks, and growth: Panel evidence. Journal of Banking and Finance, 28(3), 423-442. https://doi.org/10.1016/S0378-4266(02)00408-9

Ben Jedidia, K., Boujelbène, T., \& Helali, K. (2014). Financial development and economic growth: New evidence from Tunisia. Journal of Policy Modeling, 36(5), 883-898. https://doi.org/10.1016/j.jpolmod.2014.08.002

Boukhatem, J., \& Ben Moussa, F. (2018). The effect of Islamic banks on GDP growth: Some evidence from selected MENA countries. Borsa Istanbul Review, 18(3), 231-247. https://doi.org/10.1016/j.bir.2017.11.004

Caporale, G. M., Çatık, A. N., Helmi, M. H., Menla Ali, F., \& Tajik, M. (2019). The bank lending channel in the Malaysian Islamic and conventional banking system. Global Finance Journal, (July 2018), 100478. https://doi.org/10.1016/j.gfj.2019.100478

Carp, L. (2012). Can Stock Market Development Boost Economic Growth? Empirical Evidence from Emerging Markets in Central and Eastern Europe. Procedia Economics and Finance, 3(12), 438-444. https://doi.org/10.1016/s2212-5671(12)00177-3

Durusu-Ciftci, D., Ispir, M. S., \& Yetkiner, H. (2017). Financial development and economic growth: Some theory and more evidence. Journal of Policy Modeling, 39(2), 290-306. https://doi.org/10.1016/j.jpolmod.2016.08.001

Farahani, Y.G., \& Dastan, M. (2013). Analysis of Islamic Banks' Financing and Economic Growth: a Panel Cointegration Approach. International Journal of Islamic and Middle Eastern Finance and Management. 6(2), 156-172

Favara, G. (2003). An Empirical Reassessment of the Relationship Between Finance and Growth. IMF Working paper, WP/03/123.

Furqani, H., \& Mulyany, R. (2009). Islamic banking and economic growth: Empirical evidence from Malaysia. Journal of Economic Cooperation and Development, 30(2), 59-74. 
Grassa, R., \& Gazdar, K. (2014). Financial development and economic growth in GCC countries: A comparative study between Islamic and conventional finance. International Journal of Social Economics, 41(6), 493-514. https:/ / doi.org/10.1108/IJSE-12-2012-0232.

Goaied, M., \& Sassi, S. (2010). Financial development and economic growth in the MENA region: What about Islamic banking development?Institut des Hautes Etudes.

Hachicha, N., \& Ben Amar, A. (2015). Does Islamic bank financing contribute to economic growth? The Malaysian case. International Journal of Islamic and Middle Eastern Finance and Management, 8(3), 349-368. https://doi.org/10.1108/IMEFM-07-2014-0063

Hadi, N. (2015). Pasar Modal. Yogyakarta: Graha Ilmu.

Hammoudeh, S., Mensi, W., Reboredo, J. C., \& Nguyen, D. K. (2014). Dynamic dependence of the global Islamic equity index with global conventional equity market indices and risk factors. Pacific Basin Finance Journal, 30, 189-206. https://doi.org/10.1016/j.pacfin.2014.10.001

Hasan, M., \& Dridi, J. (2011). the Effects of the Global Crisis on Islamic and Conventional Banks: a Comparative Study. Journal of International Commerce, Economics and Policy, 02(02), 163-200. https://doi.org/10.1142/s1793993311000270

Himawan, P. (2015). The Effect of Gross Fixed Capital Formation, FDI, and Trade Openness on Economic Growth in Indonesia. Thesis thesis, Airlangga University.

Imam, P., \& Kpodar, K. (2016). Islamic banking: Good for growth? Economic Modelling, 59, 387-401. https://doi.org/10.1016/j.econmod.2016.08.004

Kassim, S. (2016). Islamic finance and economic growth: The Malaysian experience. Global Finance Journal, 30, 66-76. https://doi.org/10.1016/j.gfj.2015.11.007

King, R. G., \& Levine, R. (1993). Finance, entrepreneurship and growth. Journal of Monetary Economics, 32(3), 513-542. https://doi.org/10.1016/0304-3932(93)90028-E

King, R. G., \& Levine, R. (1993). Finance and Growth: Schumpeter Might Be Right. The Quarterly Journal of Economics, 108(3), 717-737. https://doi.org/10.2307/2118406

Lebdaoui, H., \& Wild, J. (2016). Islamic banking presence and economic growth in Southeast Asia. International Journal of Islamic and Middle Eastern Finance and Management, 9(4), 551569. https://doi.org/10.1108/IMEFM-03-2015-0037

Levine, R. (1997). Financial Development and Economic Growth: Views and Agenda. Journal of Economic Literature, 35(2), 688-726.

Mohd. Yusof, R., \& Bahlous, M. (2013). Islamic banking and economic growth in GCC \& East Asia countries: A panel cointegration analysis. Journal of Islamic Accounting and Business Research, 4(2), 151-172. https://doi.org/10.1108/JIABR-07-2012-0044

Narayan, P.K. (2004). Reformulating critical values for the bounds F-statictics approach to cointegration: An application to the tourism demand model for Fij. Department of Economics Discussion Papers No.02/04, Monash University, Melbourne.

Naqvi, B., Rizvi, S. K. A., Uqaili, H. A., \& Chaudhry, S. M. (2018). What enables Islamic banks to contribute in global financial reintermediation? Pacific Basin Finance Journal, 52, 5-25. https://doi.org/10.1016/j.pacfin.2017.12.001

Pan, L., \& Mishra, V. (2018). Stock market development and economic growth: Empirical evidence from China. Economic Modelling, 68(July 2017), 661-673. https://doi.org/10.1016/j.econmod.2017.07.005

Pesaran, M. H., Shin, Y., \& Smith, R. J. (2001). Bounds testing approaches to the analysis of level relationships. Journal of Applied Econometrics, 16(3), 289-326. https://doi.org/10.1002/jae.616

Rizvi, S. A. R., Narayan, P. K., Sakti, A., \& Syarifuddin, F. (2019). Role of Islamic banks in Indonesian banking industry: an empirical exploration. Pacific Basin Finance Journal, \#pagerange\#. https://doi.org/10.1016/j.pacfin.2019.02.002 
Budi Trianto, Masrizal, Tasiu Tijjani Sabiu. Can Islamic Finance Drives Economic Growth?: Empirical Evidence from Indonesia

Sabiu, T. T., \& Abduh, M. (2020). Islamic financial development and economic growth in Nigeria: a bounds testing approach. Journal of Islamic Monetary Economics and Finance, 6(3), 597-620.

Zarrouk, H., El Ghak, T., \& Abu Al Haija, E. (2017). Financial development, Islamic finance and economic growth: evidence of the UAE. Journal of Islamic Accounting and Business Research, 8(1), 2-22. https://doi.org/10.1108/JIABR-05-2015-0020 